\title{
Origin and Beginnings of the Protection of Authors of Works of Art
}

\author{
Václav Kramář
}

Law as a system of certain obligatory social norms ${ }^{1}$ had been evolving in European (Western) culture for a long time, a unified collection of decrees can be found already in the ancient slavery systems and in the Antiquity. This situation, however, is not the same in all branches of the legal system. We are interested in the copyright law, which for a long time was not an independent branch of the legal system although private law in general, with which the copyright law is classified, was already considerably developed. ${ }^{2}$ The Antiquity was a period of an unprecedented flowering of culture, including major works of literature, drama, fine arts. And yet, surprisingly, they existed and were spread without any chance of legal protection. The problem probably was the character of the work (a work of art) because it is the so-called immaterial (intangible) object. ${ }^{3}$ Roman

1 In legal theory two main approaches to the term law may be distinguished. Law in the objective sense of the word, in English the "law", whose definition was used above, or law in the subjective sense, in English the "right", which means the behaviour of legal subjects guaranteed by the legal norm, which mostly corresponds to the legal duty of another legal subject (authorization of one against the duty of another). More about this in e.g. Jaromír Harvánek et al., Teorie práva [Legal Theory] (Plzeň, 2008), p. $20 \mathrm{ff}$., or Ota Weinberger, Norma instituce [The Norm of the Institution] (Brno, 1995), p. 3.

2 In the history of the reflexion of legal history, earlier authors believe that the beginnings of the copyright were already known in the Antiquity. See e.g. Adolphe Breulier, Du droit de perpetuité de la propriété intelectuelle (Paris, 1855), Exupère Caillemer, La propriété litteraire à Athènes (Grenoble, 1868). This cannot be completely ruled out when we accept regarding intellectual property as a material object as the beginnings of the ownership theory; see the text above, and also e.g. Dusan Sidjanski and Stelios Castanos, Droit d'auteur ou copyright (Lausanne, 1954), p. 28 ff. However, these views were not reflected in the codified system. On this see Ivo Telec, Tvuirči práva duševního vlastnictví [Creative Rights of Intellectual Property] (Brno, 1994), p. $71 \mathrm{ff}$.

3 The term immaterial property is of key importance for the whole area of intellectual property, which includes the copyright. It is that part of the property that does not consist of things, i.e. material objects, its form is immaterial but is often expressed in an objectively perceivable form, often on the so-called material substrate. Due to this intellectual character its perception and consumption is independent of the material carrier. This does not lower its quality or quantity. Another essential 
law, the first significant complex system of legal norms was not particularly interested in it because the main aspect of the thing in general (res) was its material substance. True, even in that period there were immaterial things (res incorporales), but their substance and meanings were a little different. A major Roman lawyer, Gaius, for instance regards the inheritance as immaterial. The author's immaterial works in the modern sense of the word (e.g. a book) were put on the level of other material things - table, chair, etc. ${ }^{4}$ Therefore they were subject to the same legal regime - when e.g. an author sold his book (a finished copy is meant), a material thing, through a standard contract of purchase, he thus gave up all right to its material (see note 2, from which there followed the impossibility of further handling and owning it) and automatically also lost the right to its content, that is the imaginary copyright. ${ }^{5}$ The author's remuneration was fully replaced by the purchasing price. Unlike the still earlier eras, e.g. the primitive society, the society now already perceived the role of the author or interpreter (the two usually merged), art (music) had no longer only a magic or cultic function, and so the more surprising the position of the creator was. He could only rely on the protection of the owner, when e.g. the book was in his rightful possession, or he could appeal to a general protection as a person whose honour was involved. ${ }^{6}$ In fact only two kinds of actions were available:

feature is its capacity for being perceived and used in several places simultaneously. It is primarily an outcome of intellectual activity, such as a thought, or its direct expression (e.g. a composition). For a more detailed and wider view of immaterial property see e.g. Stanislav Vyparina, "Nehmotný majetek" [Intangible Property], Poradce podnikatelu [Adviser of Businessmen], (1993), No. 12. The area of the rights of intellectual property (further RIP), which means a system of legal norms referring to this immaterial property, can be basically divided (see Ivo Telec, Tvưrči práva duševního vlastnictvi (Brno, 1994), p. 40 ff.) into the creative RIP (e.g. creative rights to industrial property such as patent or model law; and the creative right of property other than industrial - for us are important the copyright and the associated rights, e.g. the rights of performing artists). The second main group consists of commercial (that is non-creative) RIP (again at first commercial rights to industrial property such as the right to the designation of a firm, the trade mark, etc.; and second, commercial - noncreative rights to an other than the industrial IP, such right to accoustic recording, to broadcasting on the radio or television, etc.).

4 Jaromír Kincl and Valentin Urfus, Římské právo [Roman Law] (Prague, 1990), p. 114 ff.

5 Both personal rights (in modern conception it includes the right to publication, the copyright, the important right to the inviolability of the work) as well as the property right (now the right to use the work or authorization for its use by another person (e.g. through a licence and another property right).

Here one should point out the period overcoming of the legal view that e.g. a manuscript belongs to the owner of the material on which it is written or from which it was made. On this see Štefan Luby, "Vývin ochrany autorskej tvorby v predkapitalistických spoločenských formáciách" [Development of the Copyright in Pre-capitalist Societies], Právnické stúdie [Law Studies], (1962), No. 1, p. 190.

6 Roman law differentiated between two basic groups of actions: actiones in rem, with which the right was asserted to a thing when the right was broken. And actiones in personam, directed against particular persons who were to meet an obligation. Action for ownership thus made a person respect a partial right of the plaintiff, personal actions made the plaintiff meet an obligation. On this see Jaromír Kincl, Valentin Urfus and Michal Skřejpek, Římské právo (Prague, 1995), p. 153 ff. 
actio vindicatoria (action of recovery) and actio negatoria (action to repel a claim), of course when the work was stolen, only then he could defend himself against an unjustified use - publication and interference with the work. ${ }^{7}$ In either case it was an action for protection of ownership; actio negatoria was used against less intensive interference. In actiones in personam, i.e. personal action, the injured could use a rather general action, actio iniuriarum, for protection of human dignity and the civic honour. ${ }^{8}$ In Rome, against plagiarism the special Lex Fabia de plagiariis could be applied, which covered interference with human liberty (from a moral, and in the long run even a legally theoretical aspect, the plagiarist was seen as a thief). ${ }^{9}$ These measures mainly applied to literary authors but their chances were restricted in favour of the publishers (the bibliopolae, often associated in collegiae). They often obtained manuscripts free of charge, especially if the author was wealthy because he mainly wanted to achieve glory and social prestige.

Somewhat better off were authors of works of music and dramas. These works were received - in the sense of consumption - collectively. Moreover they were made accessible to the wide people, unlike the literary works, of a more exclusive character. Music and song aroused a lot of interest in society and so they were considerably supported by the Greek state and the people in power. ${ }^{10}$ A positive role was played by the public competitions advertised for authors. They were paid for (they ensured property rights) and also provided some personal rights as to the publication and sovereignty of their work (e.g. it was forbidden to change the content of the works staged) ${ }^{11}$

Interesting in this respect was the position of slaves because many of them were authors of works of art. Roman law did not award them the legal status of a free man,

For more see Jaromír Kincl, Valentin Urfus and Michal Skřejpek, ibid., p. 182-187.

8 For more see Jaromír Kincl, Valentin Urfus and Michal Skřejpek, ibid., p. $261 \mathrm{ff}$. In general it was obligation from delicts (another group was obligations from the so-called quasidelicts), the principal delicts being: furtum (theft), rapina (robbery), unlawful damaging of another person's property (damnum iniuria datum) and defamation (iniuria), originally involving only attacks against corporal integrity (the so-called real injuries), a more modern conception in the so-called praetorian edicts included verbal affronts and attacks against chastity. The interpretations were later expanded to cases when somebody was prevented from performing his rights or from using things originally intended for a general public.

9 In this way writes the Roman poet and epigrammatist Martialis in his work Epigramaton libri (Lipsae, 1925), who thus proceeded against Fidentinus and called him Plagiarus (from this comes plagiarist), which meant "seller of souls".

10 E.g. Athens with these celebrations demonstrated the degree of their democracy, power and wealth. On this e.g. Eva Stehlíková, Řecké divadlo klasické doby [Greek Theater in the Classical Period] (Prague, 1991), p. 12 ff. It was otherwise in ancient Rome, where the interest was smaller, Greek works were all the time translated or imitated. The selection and evaluation of original Greek works was in the hands of the aediles, who were also in charge of the translation (as curatores ludorum) and paid out the rewards. For greater details see Štefan Luby, "Vývin ochrany autorskej tvorby v predkapitalistických spoločenských formáciách”, Právnické śtúdie, (1962), No. 1, p. 195.

11 If, however, the author sold the work or its manuscript, he lost, like in the case of literature, all rights to it. But he could rework, that is rewrite it and sell it again. 
did not take them as subjects of law, only as objects, and in all aspects and consequences regarded them as a thing. So the slave had no rights, could not own any property, and the works he produced were automatically owned by his master, who credited himself with their authorship and could disseminate them under his own name. ${ }^{12}$ The free author had a maecenas, ${ }^{13}$ for whom he worked and by whom he was paid.

This model of "the maecenas support" continued even in feudalism. There was the sovereign, a rich nobleman, or the Church, for whom the work was designed and by whom he was rewarded..$^{14}$ Initially, there was a cultural decline as compared to the Antiquity. This was due to the breakup of important centers of culture (Greece, Rome). Suddenly there was an absence of original works. Education was in the hands of the clergy and so culture acquired a heavily religious character. In the $13^{\text {th }}$ century the situation began to improve due to the foundation of universities. In music, however, secular work is documented already in the $7^{\text {th }}$ century. It was practised by clergymen. ${ }^{15}$ Until the appearance of the burger class (that is up to the $18^{\text {th }}$ century), it was primarily not concert music, meant for listening only, but it always had some other function beside the aesthetic - religious, accompaniment to dance or work. In the Middle Ages there was at first no need of original works of music. ${ }^{16}$ Spiritual music was also based on the monodical tunes of the Gregorian chant, originally an anonymous work. What is important is the gradual assertion of polyphony in folk songs. The "musicus" (composer, poet, adapter or interpreter, often combined in one person) was perceived by the medieval theory of music and by philosophy as a representative of utility music (often he was a vagrant man, with no rights), while higher music could be practised only by students of arts at ecclesiastical schools and universities. Artificial composing began to fully develop from the $11^{\text {th }}$ century, partly due to the strolling singers and musicians (here the art of chivalry should be noted), partly owing to the appearance of first great composers, such as Leoninus and Perotinus. The church kept preventing the penetration of these artificial (author) compositions or even the mere tunes into spiritual music. ${ }^{17}$

12 A well-known case is Aesop, the author of fables, who is said to have been born a slave.

The name is after Gaius Cilnius Maecenas, who supported many artists, e.g. Horace and Virgil.

Karel Knap, Autorské právo [Copyright] (Prague, 1960), p. 73. The musicians tended to gather in the courts of the nobility and worked for the noblemen, their maecenases. They gave them rewards but regarded all works, scores etc. as their own property. At court and among nobility they ranked as a better kind of servants. See Peter Krchňák, Autorskoprávní ochrana umělce a jeho díla v průběhu kulturního vývoje [Copyright Protection of Artists and Their Works in the History of Culture] (Prague, Filozofická fakulta Univerzity Karlovy, Theses, 2004), p. 29.

15 They composed e.g. folk religious hymns in national languages, which helped to promote Christian principles. For more on this see Peter Krchňák, ibid., p. 16 ff., or Aron Jakovlevič Gurevič, Kategorie středověké kultury [Categories of Medieval Culture] (Prague, 1978), p. $145 \mathrm{ff}$.

16 Until the high Middle Ages a great role was played by improvisation, through which certain models were established which later gradually developed into various types of music. These variants mostly were spread aurally. For more see Peter Krchňák, ibid., p. 14 ff.

17 This is what Pope John XXII said at the beginning of the $14^{\text {th }}$ century in order to save the Gregorian chant. Similar issues were dealt with more than two centuries later at the Council of Trent. 
Original secular music, however, develops further, in particular in the form of madrigals and operas. ${ }^{18}$ The second substantial aspect, beside the occurrence of original works, is the development of the notation system, that is the means of expression with which it was possible to register "uniquely" the compositions and then multiply them. ${ }^{19}$

A certain shift in development (even in the direction to copyright or at least similar types of right) was the arrival of guilds, associations of tradesmen and craftsmen, corporations of medieval burghers, which with their regulations and measures could protect their members. ${ }^{20}$ Thus after the invention of book printing, the publishers (originally the printers) associated themselves, which provided the basis for the publishing right, which historically preceded the copyright law. ${ }^{21}$ Another important tool was the institute of the privileges ${ }^{22}$ arbitrarily awarded by the sovereign. Exceptionally some authors could benefit from it but the privilege did not recognize the general right to authorship, ensuing from

18 Opera became popular especially from the baroque period, when it served as a theatre for anybody who could pay. With it a new social layer originated, the impresarios, theatre composers, stage designers, dancers, soloists.

19 Early and imprecise neumas gave way to the more accurate system of mensural notation. More on this more e.g. in Richard Rybarič, Vývoj európského notopisu [Development of the European Note System in Music] (Bratislava, 1982) and Willi Apel, Die Notation der polyphonen Musik 900-1600 (Wiesbaden, 1989).

20 They are found in the Czech lands from the $14^{\text {th }}$ century, see e.g. Emil Lhota, Remeslná bratrstva a cechy, jejich pưvod, rozkvět a úpadek [Crafts and Guilds, Their Origin, Flourishing and Decline] (Volyně, 1896). Also musicians were associated in guilds, from which they obtained division of labour and support (e.g. in Vienna the Brotherhood of St Nicholas was founded in 1588). For artistic work, in addition to the guilds there were workshops, with the master and his apprentices. On this Peter Krchňák, Autorskoprávní ochrana umělce a jeho díla v průběhu kulturního vývoje (Prague, Filozofická fakulta Univerzity Karlovy, Theses, 2004), p. 23. Gradually there came to be differentiated the concepts which in the Middle Ages were equal - the craftsman (later a pejorative work for an artist of poor quality) and the master. The guilds survived until the early $18^{\text {th }}$ century, they were finally abolished on 20 December 1859. For more details see Aron Jakovlevič Gurevič, Kategorie středověké kultury (Prague, 1978), p. $160 \mathrm{ff}$.

${ }_{21}$ Ivo Telec, Tvưrčí práva duševního vlastnictví (Brno, 1994), p. 72. For the sake of interest, let me note the first publishing privilege granted to Giovanni di Spiro on 18 Sept. 1469 by the Senate of the Venetian Republic. For greater detail on the situation in the Czech lands see e.g. Karel Kadlec, "Počátky práva autorského" [Beginnings of the Copyright], Časopis Musea královstvi Českého [Journal of the Museum of the Kingdom of Bohemia], (1893), p. $569 \mathrm{ff}$. The oldest known privilege of this kind in music was granted by Bishop Heinrich von Bamberg; after Oscar von Wächter, Das Verlagsrecht (Stuttgart, 1857). Among the first privileges were, again in Venice, Jakub Ungar (1513) and Marc de l'Acquila (1505).

22 It was either a general privilege, the right of giving a general monopoly to a particular publisher in a particular area for a particular period or it was a special privilege for the publication of an author. For greater detail see Štefan Luby, "Vývin ochrany autorskej tvorby v predkapitalistických spoločenských formáciách”, Právnické štúdie, (1962), No. 1, p. 210 ff. Publishing rights were further restricted by the regulations of state or church censorship. In Austria, state censorship of press was abolished by a patent issued by Emperor Joseph II, on 11 June 1781. 
the freedom of creative mental activity, and the right to exploit the results, although it could be in his favour; a copyright could be granted only as a single measure, a favour given by the sovereign to a particular author. ${ }^{23}$ The objective of the privileges was to protect the publisher rather than the author from a dishonest competition, especially unauthorized reprints. Here it should be noted, however, that the opinion about the unauthorized reprint changed considerably in the course of time. For instance in the Renaissance, in the interest of the widest possible spreading of the work, it was even officially supported. ${ }^{24}$ Only with the passage of time, clauses were added to the privileges, involving the consent of the author with the edition of a particular work. ${ }^{25}$

Still, in copyright and dishonest activity the long prevailing view was that the author's talent should serve everybody (and for higher glory of God) and so it was common to quote from another work (which on the contrary was regarded as an honour) and even partial intervention in other works was allowed. ${ }^{26}$ From this it logically follows that to the

23 Karel Knap, Autorské právo (Prague, 1960), p. 12.

24 Defence of unauthorized reprint persisted until the $19^{\text {th }}$ century. A noted Austrian publisher, Trattner, even published a work in defence of unauthorized reprints. See Johann Thomas Trattner, Der gerechtfertiger Nachdrucker (Wien, 1774). The first norms forbidding it, however, appeared already in the $16^{\text {th }}$ century, inspired by Roman legal provisions, the very first was the ruling by the Council of Basle in 1531. Next came e.g. the Printing Statue of Nuremberg of 1550, the Saxony Mandate of 1686 involving even non-privileged works, in England the act issued by Queen Anne in 1709, Act for Encouragement of Learning, etc. Austria-Hungary was among the last. The decree of the Court Office of 11 February 1775 forbade unauthorized reprint only of books published in Austria. This was confirmed by decrees of 1794, 1795 and 1810. Moreover, it again covered only the rights of publishers whereas copyright was given only indirect protection. As late as 1811 the publishing contract was adapted in $\S \S 1164$ an. General Civil Code. These measures together with the subsequent bilateral treaty of Austria and Sardinia of 22 May 1840 formed the basis for the codification proper of the copyright by the patent of 19 Oct. 1846. For more detail see Štefan Luby, "Vývin ochrany autorskej tvorby v predkapitalistických spoločenských formáciách”, Právnické štúdie (1962), No. 1, p. 214, note No. 89 and p. 237 ff.

25 The natural-legal theory and the ownership interpretation of the copyright were to blame for this (see further in the text). The first men to point it out were John Locke and Denis Diderot; the latter in the writing Lettre sur le commerce de librairie (Paris, 1861). But still the privileges continued to be issued for a greater profit of the publishers. There was, however, another variant, namely that the author himself obtained the privilege for the publication of his work. He could choose the publisher. But because until the $16^{\text {th }}$ century there was no unified evidence, several publishers were entitled to publish a particular work. For this see Štefan Luby, ibid., p. 215 ff. and 220 and Ivo Telec, Tvưrčí práva duševního vlastnictví (Brno, 1994), p. 73.

26 E.g. Nicola Machiavelli in his writing Discorsi sopra la prima Deca di Tito Livio assessed plagiarism only according to whether a new artistically valuable work was derived from it. Another example is the opera at the turn of the $17^{\text {th }}$ and $18^{\text {th }}$ century, on this see e.g. Dominique Fernandez, Porporino aneb Tajnosti neapolské [Porporino or the Secrets of Naples] (Prague, 1999), p. 172 and 281. Composers commonly made use of the works of their predecessors (music and libretto) because the staging of a completely new work was too great a commercial risk. So it was nothing else but a period show business, by which this practice continued to be justified. Another factor was the great role of the prima donnas and their often scandalous conduct described in press. 
authors (with some exceptions) for a long time no privileges were granted to guarantee their protection or a minimal profit. ${ }^{27}$

The situation with the paying the author's fee was not simple either because in the historical development this activity did not correspond to the period morale. It was customary for the author to obtain copies of his work from his publisher and sometimes even free copies of another author. ${ }^{28}$ Authors and composers were thus obliged to get money by other means. "Dedication" was a personal dedication of a work, for which the author usually expected a sponsoring gift. The issue of the author's remuneration became relevant as late as in the middle of the $16^{\text {th }}$ century (in works of music at the beginning of the $18^{\text {th }}$ century), ${ }^{29}$ but it was often merely a symbolic sum or a non-pecuniary gift. When the composer sold the score, his profit was greater but he lost the rights to the work. ${ }^{30}$ A certain legal breakthrough came with the decree issued by the French Royal Council on 15 September 1786, which for the first time guaranteed the author's right to a fee as well as the right to give permission to publish a work of music and perform it in public. ${ }^{31}$

A substantial breakthrough came with the application of the natural-legal theory of authorship, which tried to define the author's rights (first attempts are found already in the $16^{\text {th }}$ century) by means of the personal-legal conception of the theory of ownership and thus of everything that was created (including intellectual property).$^{32}$ In the first place, the idea of the privilege became absurd, the idea of an act of the arbitrary decision of the sovereign, as a basis for someone's right. Besides, if it was a monopoly position, it was against the principle of freedom, which was the principal issue for the supporters of the natural-legal theory. ${ }^{33}$ So the first effort was to make the privilege, if at all, meet the role of at the most a secondary source of the right. From the $17^{\text {th }}$ century in England and the

27 When this happened, it was mostly up to the level of the expenses and only when the work had any social value. Privileges were acquired rarely at first and they mostly included the right to spreading by the publisher chosen by the author, but there are also beginnings of other rights such as the right to the designation, integrity, or after the Roman model the right to protection against unlawful publication of a still unpublished work (that is against plagiarism).

28 On this Karel Kadlec, "Počátky práva autorského", Časopis Musea království Českého (1893), p. 355. Here is mentioned J. A. Komenský (Comenius), who sent his writings to noted people and himself collected payment. Kadlec regards this behaviour as undignified begging, to which Komenský was driven by circumstances.

29 See Štefan Luby, "Vývin ochrany autorskej tvorby v predkapitalistických spoločenských formáciách", Právnické štúdie (1962), No. 1, p. 231.

30 Olga Pitelová, Vývoj a ochrana autorských práv v oblasti kultury [Development and Protection of Copyright in the Sphere of Culture] (Brno, Právnická fakulta Masarykovy univerzity, Theses, 2007), p. 20.

31 After France it was Landrecht in Prussia, the Austrian General Cuivi Code and in the USA a law of 1831. For detail see Štefan Luby, "Vývin ochrany autorskej tvorby za kapitalizmu" [Development of the Copyright under Capitalism], Právnické štúdie (1966), No. 1, p. 22.

32 Ivo Telec, Tvưrči práva duševního vlastnictví (Brno, 1994), p. $73 \mathrm{ff}$.

33 Augustin-Charles Renouard, Traité des droits d'auteur I-II, vol. 1 (Paris, 1838), p. $111 \mathrm{ff}$. 
$18^{\text {th }}$ century in France, according to the legal theory, the privilege could not be held even for a secondary source. ${ }^{34}$ The author's work continued to be identified with its material substrate, ${ }^{35}$ finally it was separated from it but continued to be regarded as a common thing. Only with the passing of time the teachings of Immanuel Kant ${ }^{36}$ and Johann Gottlieb Fichte ${ }^{37}$ came to the forefront. Their theory of a really personal conception prevailed over the theory of ownership at the expense of the so-called intellectual property. It tried to explain the substance of the copyright as an ownership right sui generis, which is bound to the immaterial substance of the work. According to some critics, however, the authors should be granted some right even after the alienation of their works - e.g. the right to ownership, which in those days was by no means common. ${ }^{38}$ The conceptions of Kant

34 This is shown by the new laws and decrees - in England already in 1709 (see note 24), where this act by Queen Anne can be regarded as the oldest copyright law sui generis. Next came France with its decrees of 1723 (the result of the struggle between the publishers and authors, in which the publishers won) and 1777 (there the authors were awarded the right to publish and sell their works). A similar statement came from Landrecht in Prussia in 1791. See Štefan Luby, "Vývin ochrany autorskej tvorby za kapitalizmu”, Právnické štúdie (1966), No. 1, p. 7 ff.

35 By this the marketability of the thing was secured for the author. The commercial element was emphasized. But the theory did not count enough with cases when a work existed in several copies, which enabled an unfair competition between holders of the copies. See Štefan Luby, ibid., p. 12.

36 In the work Metaphysichen Anfangsgründe der Rechtslehre (Königsberg, 1797) he required a strict differentiation between a work as such and a mere material substrate. For him the work is not a piece of goods but a manifestation of the author's personality and the freedom towards the public, a product of creative ability. Thus it cannot become an object of trade, no one has the right of ownership to it - not even the author. But he is allowed to use it - it is his inalienable personal right of as well as the exclusive right to decide when and how he will publish his work (if he wants to). Kant believes that the publisher mediates the author's thoughts to the public. He defined his position by the right to use of an obligatory character. Kant's ideas were developed by other authors of personal-legal theories.

37 His work "Beweis der Unrechtsmässigkeit des Büchernachdrucks”, Berlinische Monatsschrift, 21 (1791). He also distinguished the two levels, like Kant, but saw the copyright as an ownership law. The material substrate is an alienable thing, the intellectual content belongs to the author only up to the moment of its publication. He explicitly speaks of the form of the work, which is a manner of the expression of the thoughts and nobody can own it, it is the inalienable right of the author. This mostly formal theory by Fichte was not without faults - when someone "merely" imitated the author or did not keep the exact form of the work, this was not regarded as breaking the right. Fichte was developed by the authors of the conception of intellectual property. Among those who contributed to this conception were the philosophers Georg Wilhelm Friedrich Hegel, the book Philosophie des Rechts (Berlin, 1821), in which he speaks of the inalienability of the material in contrast to the work, and Arthur Schopenhauer, the book Sämtliche Werke I. (Leipzig, 1873). The object of the copyright is the work as an immaterial object and so it is necessary to speak of a specific intellectual property.

38 The supporters of the theory of ownership law sui generis are e.g. Karl Ernst Schmid, Büchernachdruck (Jena, 1823) and Wilhelm Traugott Krug, Kritische Bemerkungen über Schriftstellerei, Buchhandel und Nachdruck (Leipzig, 1824). From the critics let us mention Johann Stephan Pütter, Der Büchernach-druck nach ächten Grundsätzen des Rechts (Göttingen, 1774). Quoted after Štefan Luby, "Vývin ochrany autorskej tvorby za kapitalizmu", Právnické štúdie (1966), No. 1, p. 13 and 15. 
and Fichte were finally developed by Otto Girke ${ }^{39}$ into the monistic theory (personal and property rights are inseparable) and at the same time a personal theory (transferability only of the right of further use of the work, which obliged the authors most) ${ }^{40}$ At the end of the $18^{\text {th }}$ century the privilege system was gradually replaced by the first state legislation. ${ }^{41}$

In conclusion, let me illustrate the general situation of the social status of the authors in this period on the example of a world-famous composer, one of the principal representatives of classicism in music. The interest of the publishers in works of music was much smaller than in works of literature. Their reproduction was costlier and the sales much lower. Things slightly improved only when music arrived in the bourgeois society and home performances of music as well as concerts became popular. Many authors, however, either published their works at their own expense (e.g. Wolfgang Amadeus Mozart ${ }^{42}$ ), or used a maecenas or an employer. Ludwig van Beethoven had several maecenases in notable aristocratic families. ${ }^{43}$ Their names were often mentioned in the works. For a long time he also published his music (e.g. in the Viennese firm Artia \& Company) in subscription, which was a sort of contract between the publishing house and the author, in which the latter pledged to find several subscribers to a certain number of copies. It was a common practice for beginning or not very well-known authors. ${ }^{44}$ Another institution used by Beethoven was the dedication. His Third Symphony, Eroica, even has

39 Deutsches Privatrecht I. (Leipzig, 1895).

40 As a contrast to this monism, at the end of the $1^{\text {th }}$ century dualistic theories were developed (they distinguished personal and property rights but only the latter were regarded as alienable and temporarily limited).

${ }^{41}$ See note no. 34. Further it is the decree of the French Constitutional Assembly in 1791 and 1793 about the protection of IP bound to a drama or a work of music. The direct initiators were the authors organized in the Society of Authors (headed by Beaumarchais). Among the other decrees there is the Saxon mandate of December 1773, the Dutch act of November 1796, which suddenly abolished the whole system of privileges, and the same was done by the Civil Code in Baden in 1809. Attempts at a German all-imperial adaptation of these legal relations were successful only in 1837, and that was due to the conservative governments in Austria and Würtembersg. They were overtaken even by the Csarist Russia, which cancelled the privileges in 1828. For more details see Štefan Luby, "Vývin ochrany autorskej tvorby za kapitalizmu”, Právnické štúdie (1966), No. 1, p. 18-22 and $26 \mathrm{ff}$.

42 Štefan Luby, "Vývin ochrany autorskej tvorby za kapitalizmu”, Právnické śtúdie (1966), No. 1, p. 21.

43 One of them was Prince Karel Lichnovský, who from 1800 paid an annual pension of 600 guldens. Among other maecenases was František Josef Lobkowicz, who bought for Beethoven some of his compositions, e.g. Eroica, which had its premiere in the Lobkowicz Palace in Vienna. Lobkowicz also organized subscription concerts for him (it was a form of subscription to concerts, like today). The Kinsky family also paid Beethoven a life annuity (the original amount of 4,000 guldens during the great inflation in Austria was cut in 1811 to one fifth and was paid out irregularly). Beethoven even started court proceedings about it, which finally, in 1815, were decided in favour of the plaintiff. For greater details see Jan Racek, Beethoven a české země [Beethoven and the Czech Lands] (Prague, 1964), p. 15-31.

44 Olga Pitelová, Vývoj a ochrana autorských práv v oblasti kultury (Brno, Právnická fakulta Masarykovy Univerzity, Theses, 2007), p. 24, an interview with Professor PhDr. Miloš Štědron, CSc. 
a double dedication. The original dedication to Napoleon Bonaparte was cancelled by Beethoven when Napoleon crowned himself Emperor of France, on 2 December 1804, thus betraying Beethoven's idea of democracy. Next he dedicated the work to his own maecenas, Prince Lobkowicz.

For the sake of completeness let me add that protection of dramatists in this period of early conceptions of the copyright was falling behind ${ }^{45}$ (many dramatists often were simultaneously directors of various theatres), and that the situation was a little different in fine arts because these artists had a better real as well as legal position. ${ }^{46}$

In these main theses we attempted an outline of the historical development of what was known about copyright and how important the author's work was. This survey started with the first ancient legal systems and deliberately finished before the development (and a more exact identification) of the first independent codifications of the copyright. This is approximately the turn of the $18^{\text {th }}$ and $19^{\text {th }}$ century and raises the issue of intellectual property from the level of merely partial ideas, alternative and not always effective solutions, to the sphere of an adequate and binding legal system. The following period (starting approximately in the $19^{\text {th }}$ century) brought numerous changes in the technology of reproduction of music. The $20^{\text {th }}$ century added the no less revolutionary opportunities in music, law was codified on national and international levels. That period has its specific features and both its complexity and size deserve a separate study.

We can see that in history the profession of artists was relatively invidious from this respect. We should realize that in law the specificity of art was for a long time ignored. Artists simply could not invoke their rights, works of art were regarded as material objects and were handled in that way. Only later this idea gave way to the new conception of intellectual property. The one area in which the idea of a work of art dominated, was literature. This set (with some exceptions) general boundaries, from which the rest of arts did not deviate very much. I believe that I succeeded in turning attention to the most essential aspects leading to the origin of adequate legislation in this field.

Translated by Jaroslav Peprník

45 In some cases some rulings did harm to the authors. E.g. when a play did not bring a particular minimum of profit, or was a complete failure, it became a "free work" (domaine public) and the author had no right to a fee, even when later the work "took on" and was successfully performed. On this see Karel Kadlec, "Počátky práva autorského”, Časopis Musea království Českého (1893), p. 131 ff.

46 More on this in Štefan Luby, "Vývin ochrany autorskej tvorby v predkapitalistických spoločenských formáciách”, Právnické štúdie (1962), No. 1, p. 233 ff. Here should be remembered a peculiarity, the institute of collective copyright awarded from the $16^{\text {th }}$ century to various brotherhoods and associations of fine artists. In France by a decree of 1676 and in England by a decree of 1735 these organizations of artists even enforced the exclusivity of their right to reproduction and propagation of their works. This protection, however, never covered works of architecture. 


\section{Das Entstehen und die Anfänge des Urheberschutzes für die Autoren von Kunstwerken}

\section{Zusammenfassung}

Bei unserer Suche nach den Wurzeln des Urheberrechtes selbst müssen wir nicht in eine allzu weite Vergangenheit zurückgehen. Etwas anderes ist es aber, wenn wir versuchen, die ersten Bemühungen um eine rechtliche Auffassung des urheberischen Schaffenswerkes, einzelner Produkte und der Stellung der Autoren nachzuvollziehen. Dazu lassen wir uns bis in den Zeitraum des antiken Griechenlands und Roms zurückführen, wobei aber deren Rechtssysteme nicht in der Lage waren, den Begriff des immateriellen Eigentums zu erfassen. Die Urheberwerke wurden deswegen als bewegliche materielle Gegenstände behandelt. Über die entsprechenden Rechte verfügte also derjenige, der die Sache in Besitz hat, mit dem Verkauf der Sache verzichtete der Autor auf jedwede Rechte. Sollte das Werk entwendet werden, gab es zum Schutz der Rechte nur allgemeine Sachklagen. Zum Ehrenschutz konnte dann der Beschädigte eine Privatklage gegen die Person, die das Werk unberechtigterweise nutzte, veröffentlichte oder darin eingriff, einreichen. Die plagiatorische Aneignung eines Werkes, was man als Diebstahl ansah, wurde in Rom mit Hilfe der Lex Fabia verfolgt. Autoren von musikalischen und dramatischen Werken beteiligten sich an öffentlichen Wettbewerben, die ihnen ein gewisses Maß an Urheberschutz für ihre Werke gewährleistete. Zu den häufiger vorkommenden Erscheinungsformen gehörte das Mäzenatentum.

Das Mittelalter setzte einige Trends, wie zum Beispiel die Tätigkeit von Mäzenen, fort, wobei diese Rolle von der Kirche, den Adeligen oder den Herrschern übernommen wurde. Am Anfang mangelte es an ursprünglichen Urheberwerken, lange Zeit unterstützte man sogar die Herstellung von Plagiaten. Auch die Stellung der Kirche und ihre Bemühungen um die geistige Reinheit der Musik spielten hier ihre Rolle. Es entstanden sogenannte Zünfte, Berufs- und Standesvereine zum Schutz der Interessen ihrer Mitglieder. Darüber hinaus wurden von einem Herrscher Privilegien als einmalige Berechtigungen zu einer gewissen Tätigkeit verliehen, durch welche die Autoren meistens zu Gunsten von Herausgebern benachteiligt wurden. Mit der Zeit verbesserte sich die Situation durch verschiedene Eigentumstheorien für das urheberrechtliche Schaffen der Künstler und später auch durch eine personalrechtliche Verfassung der Anhänger des natürlichen Rechts. Der Autor tritt in den Vordergrund, sein Werk wird als sein geistiges Eigentum betrachtet. Derartige Theorien, die unter anderem von Kant und Fichte angedeutet wurden, trugen zu den ersten Kodifikationen des Urheberrechtes im 18. Jahrhundert (England, Frankreich) bei. Es ist zu erwähnen, dass man noch lange versuchte, die Auszahlung der Urhebertantiemen zu umgehen, und die Vergütung zum Beispiel durch freie Exemplare, Dedikationen und Subskriptionsverträge mit den Herausgebern zu ersetzen. 


\title{
Vznik a počátky právní ochrany autorů uměleckých děl
}

\begin{abstract}
Shrnutí
Chceme-li se dopátrat kořenů samotného autorského práva, nemusíme chodit daleko do minulosti. Něco jiného však znamená pokusit se vysledovat první snahy o právní uchopení autorské tvorby, výtvorů a postavení jejich tvůrců. To nás vede až do období antického Řecka a Ríma, jejichž právní systém však nedokáže vystihnout pojem nehmotného vlastnictví a nakládá s autorskými výtvory jako s běžnou hmotnou věcí. Práva k ní má ten, kdo věc drží, prodejem se autor zříká všech práv. K ochraně slouží obecné věcné žaloby, pokud je dílo zcizeno, k ochraně cti pak může poškozený použít osobní žalobu proti tomu, kdo dílo neoprávněně užívá, zveřejní či do něj zasahuje. Plagiátorství, brané za krádež, stíhá v Římě Lex Fabia. Autoři hudebních a dramatických děl využívají veřejné soutěže, zaručující jim jistou ochranu výtvorů, hojně se též pěstuje mecenášství.

Středověk v některých trendech pokračuje, např. v mecenášství, jehož role se ujímá církev, šlechtici či panovník. Zpočátku chybí původní autorská tvorba, plagiátorství je dlouho dokonce podporováno. Svou roli hraje i postavení církve a její snahy o duchovní čistotu hudby. Vznikají tzv. cechy, profesní a stavovská sdružení, dbající na zájmy svých členů. Vedle toho panovník uděluje privilegia, jednorázová oprávnění k určité činnosti, většinou diskriminující autory ve prospěch nakladatelů, časem se situace zlepšuje rozličnými vlastnickými teoriemi autorské tvorby a posléze osobněprávními pojetími stoupenců přirozeného práva. Do popředí se dostává autor, dílo je jeho duševním vlastnictvím. Tyto teorie nastíněné mj. Kantem a Fichtem pomáhají k prvním kodifikacím autorského práva v 18. století (Anglie, Francie). Rovněž autorská odměna je dlouho nahrazována a obcházena př. výtisky děl zdarma, dedikacemi, subskripčními smlouvami s nakladateli.
\end{abstract}

\section{Keywords}

Work of art; music copyright; law. 